\title{
Ergonomic analysis in the bagging of gran equipment: unsuitability of the work stations
}

\author{
Suzi Mariño ${ }^{\mathrm{a},{ }^{,}, \text {Leandro Lemos }}{ }^{\mathrm{b}}$ \\ ${ }^{a}$ Department of Design, State and Federal University of Bahia, Rua Teixeira de Barros, 800/607-B, Brotas, CEP \\ 40.279-080, Salvador, Bahia, Brazil \\ ${ }^{\mathrm{b}}$ Department of Production Engineering, Faculty of Science and Technologists - AREA 1, Rua Teixeira de \\ Barros, 800/607-B, Brotas, CEP 40.279-080, Salvador, Bahia, Brazil
}

\begin{abstract}
This analysis was performed in the industry for bagging grain (granular urea) nitrogen fertilizer factory in order to raise the causes of accidents on the operators. Data collection through direct observation and interviews done with the managers and operators have identified the causes of accidents. The results show an evident fact: the working conditions of bagging grain cause embarrassment to the employee, as well as the emergence of pathophysiology due to overload, then the problems of work organization involving mainly equipment, tools and accessories inadequate. At the end of this work are related suggestions, which has as its goal the reduction or even elimination of accidents involving operators bagging grain.
\end{abstract}

Keywords: Bagging grain, Ergonomic Analysis, Occupational Biomechanics

\section{Introduction}

This research was conducted in the industry for bagging grain in nitrogenous fertilizer plants in order to analyze the characteristics of the activities of bagging grain and its relationship with the severity level for operators

The ergonomic analysis was the basis for this research. Data collection done by means of direct observations and interviews with managers and workers have identified the causes of the severity scores in the tasks of the operators. It was possible to identify that, for workers, the inadequacy of the job is one of the reasons that cause accidents. At the end of this research is a related suggestion, which aims to reduce or even eliminate the risks of accidents and discomfort / pain alleged by the workers.

The results demonstrated an evident fact: the working conditions in Bagging grain cause workers to physical constraints, such as the appearance of lesions due to biomechanical overload, followed by problems involving the organization of work, tools, accessories and especially inadequate equipment, hazards accidents to slip and fall off when the equipment, tensions in the shoulders, back and lower limbs and malaise generated by noise.

\subsection{Bagging grain}

The industries of granulated urea, nitrogen, ammonia and nitric acid for use in several product areas for the manufacture of medicines, food for cattle and planting among others, adopt the process of bagging Bagging grain for the urea comes in bags to the final customer. The packaging can be done in two ways: Big Bags or sacks of $25 \mathrm{~kg}$, but the packaging of choice for customers is $25 \mathrm{~kg}$ sacks where handling, according to them, it becomes easier to use in the field or industry. This research is being analyzed the bagging grains model 302 LA or LB. (Figure 1)

\footnotetext{
*Corresponding author. E-mail: suzimarino@gmail.com.
} 


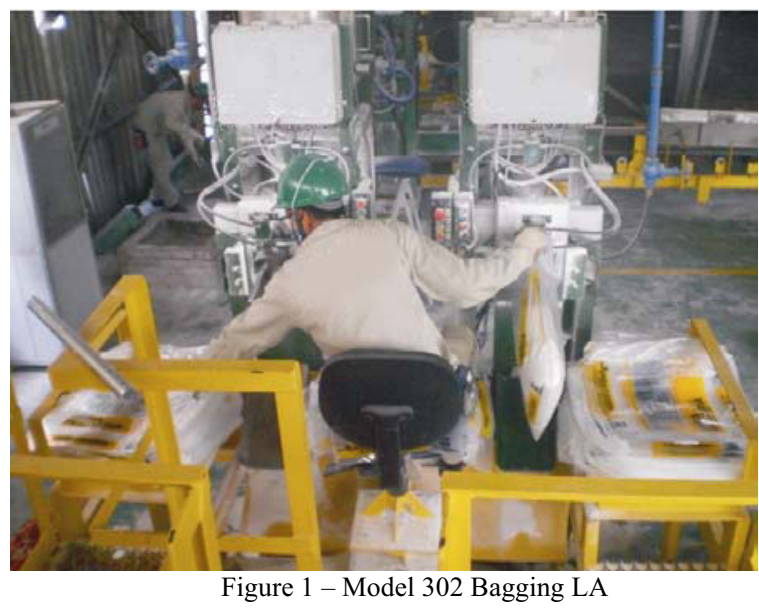

The granulated urea, hitherto imported in its entirety, drives the Brazilian agribusiness. In 2005, consumption of urea in Brazil was 2.5 million tons. Of this total, 390,000 tons are granulated urea, which represents $16 \%$ of the market. According [6], the annual production of urea by Petrobras is 180 thousand tons, or almost half of domestic consumption. Thanks to the strengthening of agriculture in the country, the potential market for granulated urea is estimated at 1.2 million tons a year.

Crops that require more granular urea are corn, sugarcane, coffee, rice, cotton and the set consisting of pasture, fruits and vegetables. The Brazilian market for urea reflects the type of crop produced in each region. The production of Petrobras's main markets the states of Mato Grosso, Bahia, and Goiás.

\subsection{Objective}

Identifying ergonomic problems in the activity of the bagging operator of grain in order to minimize accidents, human costs and increasing, consequently, productivity.

\subsection{Justificative}

The activity of grain bagging is an activity that requires great physical effort of the professional. During his work day, the operator performs repetitive movements such as flexion of the spine in the region providing the appearance of lesions due to biomechanical overload, followed by problems involving the organization of work, tools, accessories and especially inadequate equipment, the risk of slipping accidents and fall when getting off the equipment, tension in the shoulders, back and lower limbs and malaise generated by noise. According to [7], the pain caused by movements of the lumbar spine involves a defective movements committed, or in a column structurally normal, functioning improperly. Pain involves the kinetic irritation of tissues sensitive to pain, caused by movements of the spine; this occurs with the loss of productivity that under appropriate conditions for its activity the employee may even increase production. Hence the need for analysis and modification of jobs bagging of grain given the constraints that operators are exposed is essential to ensure their health.

\section{Method}

The methodology used in this study was based on the concepts of the system ergonomic man $\mathrm{x}$ task $\mathrm{x}$ machine as [1]. Noting the positions of operator bagging grain, suggesting improvements in the desktop, so you can identify, categorize, prioritize, and propose solutions to the problems encountered. Developed for this research was an ergonomic assessment, which exploits phase that maps all ergonomic problems found at the scene observed with the application of systematic and questioning System Man $\mathrm{x}$ Task $\mathrm{x}$ Machine, ergonomic opinion, Technical GUT Gravity x Urgency x Trend and application of Rating Scale Pain/discomfort.

\section{Results}

\subsection{Definition of the problem}

Was observed the activity bag and photographed in an unsystematic manner. We identified several inappropriate situations such as posture, excessive heat and that more attention has been called the extension which performs bagger to get the sacks in the tray. According to [2], some factors identified in the realization of the process can influence to the beginning of some diseases, and exposure to environmental physical and postural problems.

\subsection{Formulation of the problem}

In order to make clear the specific problems of the activity, they are now in terms of depth and detail explanation categorization and taxonomy of ergonomics problems, as guide [1] in Figures 2-7. 


\subsubsection{Interfacial problems}

Prejudicial postures resulting from inadequacies of sight / outlet information, wrap ational / scope, communications of component placement, with damage to the muscular and skeletal system [1].

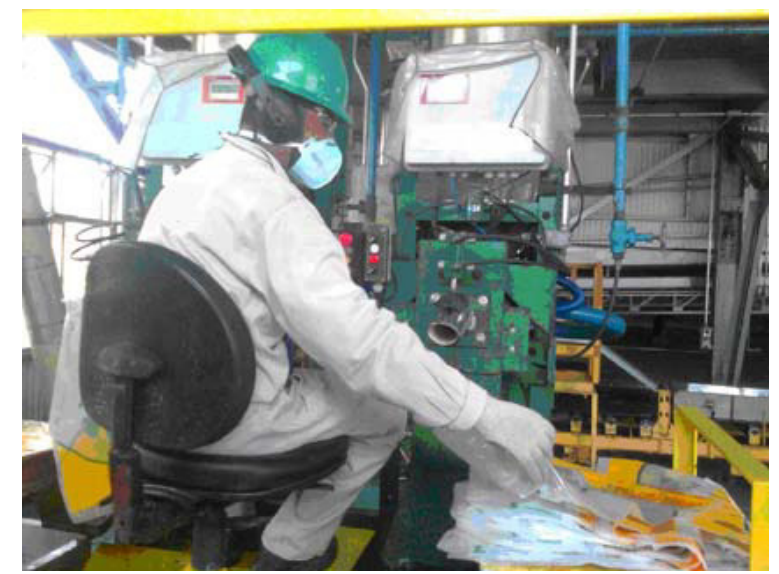

Figure 2 - Temperature bothering noise generated by the equipment operator during the execution of the task resulting in headaches.

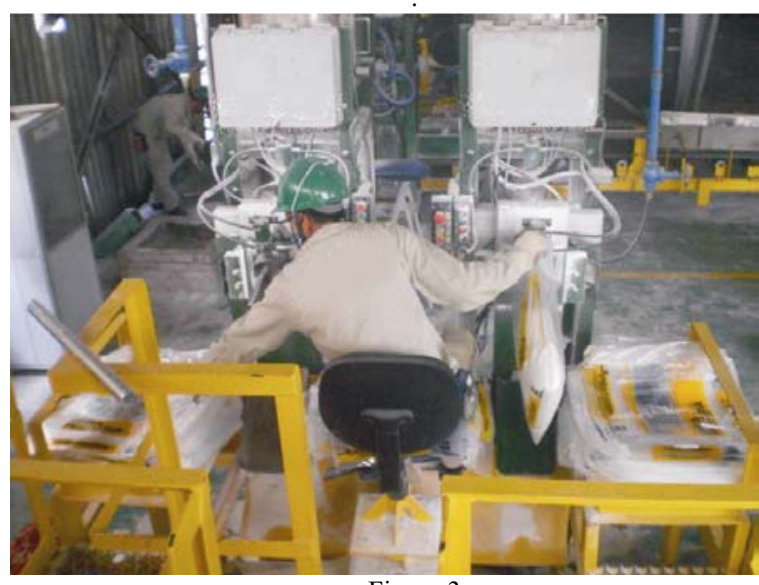

Figure 3

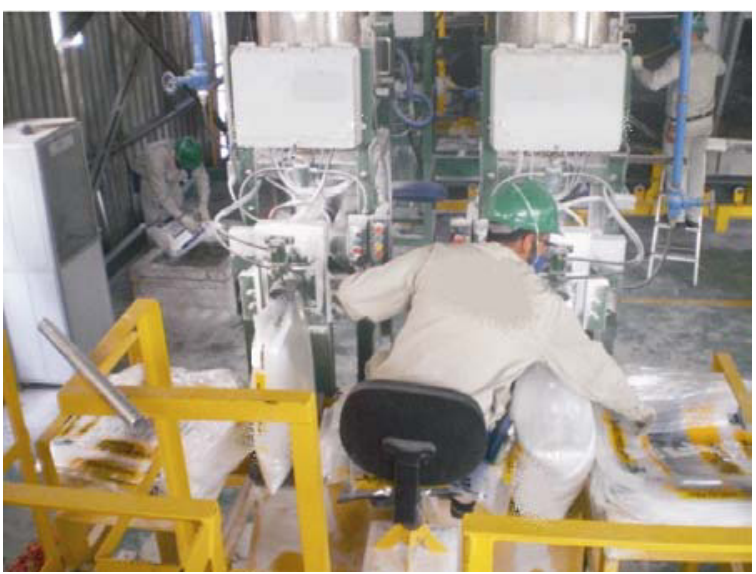

Figure 4

Figures 3 e 4 - Operator performs lateral flexion of the trunk with his left arm extension. Resulting in low back pain

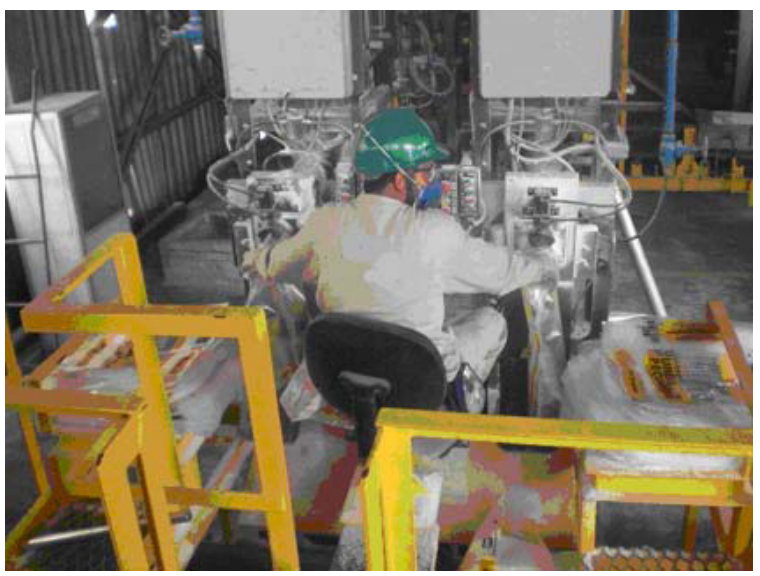

Figure 5 - Efforts postural occur with the repetition of movements and lack of a comfort zone for the upper limbs resulting in pain in the arms and back.

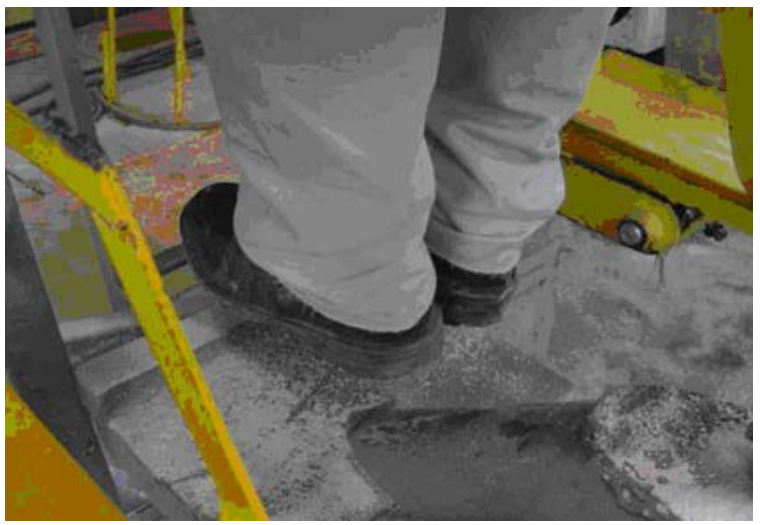

Figure 6 - Operator can not support your feet to the mat resulting in tension in the lower risk of falls. 


\subsubsection{Accidents problems}

Commit insurance requirements involving the safety of the work, at home and at work, and lack of protection of machinery, soil instability, scaffolding, ramps and stairs, poor maintenance routines deficiency and equipment for emergencies and fires. [1]

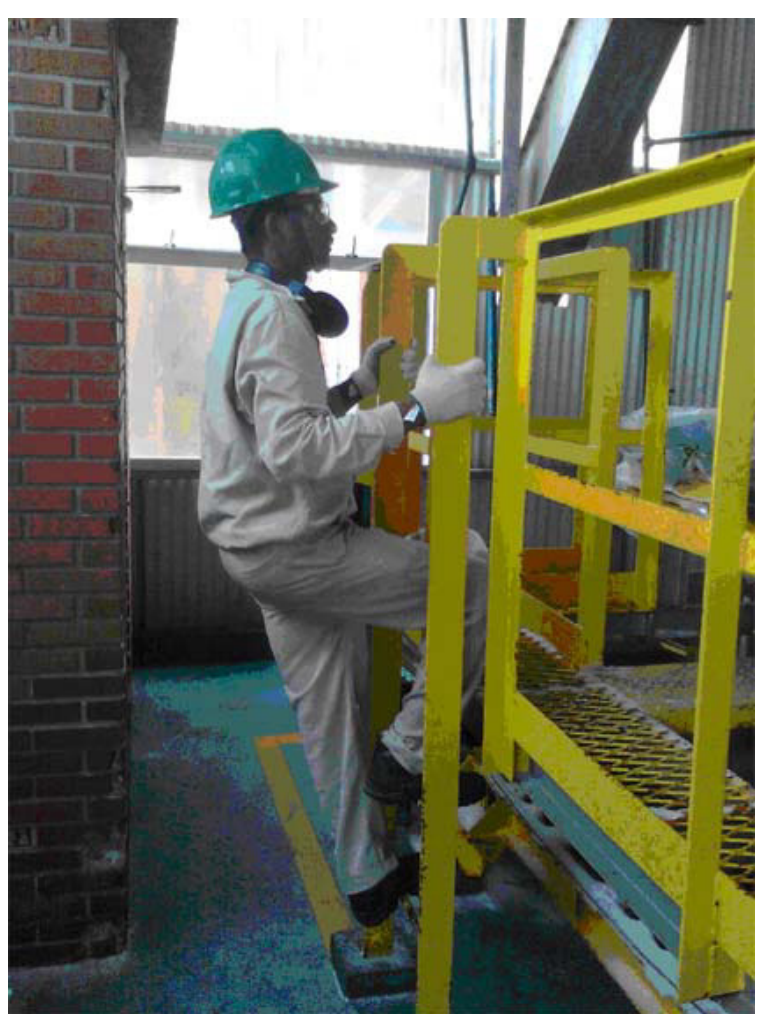

Figure 7 - Risk of falling when getting on and off the job.

\subsubsection{Sensory-physiological problems}

These problems are associated with fatigue caused by excessive noise from the machinery used in the Bagging grain, causing fatigue and loss of attention and reflection.

\subsubsection{Psychoneurophysiological problems}

These problems are associated with the possibility of nervous fatigue as a result of the operator only stop working when the truck is fully loaded or the amount stored in the shift. Because of this, changes can occur in the digestive system and cardiovascular function in tasks that require close attention.

\subsection{Human costs}

The human costs as well as the cognitive load, the user's physical and mental, are caused by lack of compliance with requirements that make it possible to maximize ergonomic comfort, satisfaction and wellbeing, ensure safety, minimize constraints and optimize the performance of the task, labor income and productivity of man-machine system.

According [5], occupational diseases often represent the conditions that can damage tendons, synovium, muscles, nerves, fascia and ligaments, isolated or associated with or without tissue degeneration, affecting mainly the upper limbs, scapular region and spine. May arise in combination or not, and forced by repeated use of muscle groups and maintaining postures.

Some of the major work-related musculoskeletal disorders are tendonitis and tenosynovitis of the forearm muscles, lumbrical muscle myositis and fasciitis of the hand, biceps tendinitis, tendinitis of the supraspinatus muscle, inflammation of the pronator teres muscle with compression of the median nerve; ganglion cysts in the wrist, de Quervain tendinitis, ulnar nerve compression, carpal tunnel syndrome, radial nerve entrapment, thoracic outlet syndrome, medial and lateral epicondylitis, bursitis of the elbow and shoulder, neck tension syndrome and back pain.

The position is not ergonomic at work is one of the most frequent causes for back pain, sprains and strains specifically the muscles and ligaments of lumbar spine osteoarthritis and bone spurs. The spine, on the biomechanical aspect of three-dimensional (allows movement in three spatial planes: frontal, sagittal and transverse), absorbs external impacts to property, however, when they are excessive or inadequate, the losses are well known and often irreversible.

The back injuries are related to five aspects of manual handling in the workplace, according [5]:

- Load too heavy: over 25 pounds already is harmful to any person, being a shortlined (biotype unfavorable) is worse. This is because the intervertebral disc that has the ability to cushion the loads, it is sufficient if this charge is high for a long time or repeatedly;

- Loads large: it is impossible to observe basic rules of how to lift and transport, leading to muscle fatigue;

- Load difficult to achieve: if, to achieve the load needed to stretch the arms, fold or raise your legs, bend or twist the trunk, requires greater muscular strength. If you combine the movements of the trunk rotation with tilt, makes even more severe stress on the intervertebral disc, this can lead to degeneration and / or herniated discs; 
- unbalanced or unstable loads: this leads to uneven loading of the muscles leading to fatigue due to the fact that the center of gravity of the object being away from the center of the body of the worker, and this requires a higher torque to move, generating greater energy;

- Load difficult to grasp: this can cause the object to slip and cause an accident. In an attempt to grab the object, the worker can perform abrupt movements, which may cause micro lesions in tendons, bursae, ligaments, or any other structure of the musculoskeletal system.

The author also points out that the risk of back injury increases if:

- tasks are too much, too long and strenuous, it is not possible for the structures of the musculoskeletal system will reconvene;

- require awkward postures or movements, eg bent or twisted trunk, arms raised;

- require repetitive movements, repetitive movements generate tissue microdamage, if heal generating microfibroses, leading to capsular adhesions, tendon degeneration and inflammation in peripheral nerves that can lead to decreased muscle strength.

According to [5], when a person has an injury caused by occupational biomechanics overload, the etiologic factors are associated with the organization of work mainly involving equipment, tools, accessories and furnishings inadequate; disregard for the position; incorrect techniques to accomplish tasks; improper postures, excessive force used to perform tasks; dynamic biomechanical overload, use of instruments with excessive vibration, temperature, ventilation and humidity inappropriate in the workplace. It is then that an organized work environment, with well trained and conditioned with respect to ergonomic factors and the biomechanical limits, certainly reduces the risk of triggering so-called occupational diseases.

\subsection{Ergonomic advice}

The opinion includes a summary of the ergonomic problems seen in Table Formulation of the Problem, Preliminary Suggestions for Improvement, the prioritization and consolidation of the Problem, Predictions and Conclusion [1].

According to the results of systematic and questioning of system man $\mathrm{x}$ task $\mathrm{x}$ machine, it was possible ergonomic drafting this opinion.
The problems encountered in the questioning of system man $\mathrm{x}$ task $\mathrm{x}$ machine were interfacial, physical environment, the accident, sensory-physiological psiconeurofisiológicos and psychosocial (stress caused by the pace of activity).

Task analysis shows poor planning of the environment in terms of layout, temperature, lighting, design, impose on operators the most incorrect postures that can cause injuries and fatigue result in the need of too much physical effort and noise variance with the recommendations.

Task analysis shows poor planning of the environment in terms of layout, temperature, lighting, design, impose on operators the most incorrect postures that can cause injuries and fatigue result in the need of too much physical effort and noise variance with the recommendations.

Table 1 shows the problems selected from those presented during the questioning with preliminary suggestions for improvements.

\subsection{Technical GUT-Gravity X Urgency X Tend}

A technique proposed by [1], called GUT (Gravity $\mathrm{X}$ Urgency $\mathrm{X}$ Trend) aims to facilitate this prioritization. To prioritize actions to be implemented, making three questions about each problem encountered. First question is how serious the deviation? This question raises new questions: What effects will emerge in the long term, if the problem is not corrected? And what impact the issue of things, people and results? After following these answered the question about what the urgency of addressing the problem relating this to the time available to solve it. And lastly, what the trend of the deviation and its growth potential. This question will lead to questions about the future; the problem will become progressively larger? Or would tend to diminish and disappear by itself?

This technique allows addressing situations as a whole, ranking problems and deciding on which to begin. "Solving simultaneously all the issues raised may be impossible, ineffective or even counterproductive." [1]

The author suggests that the ergonomist proceed with the evaluation GUT with all, or the maximum number of system operators. Well, this allows a participatory assessment and provides subsidies for the suggestions and conclusions of the assessment stage of 
Table 1

Ergonomic advice: Formulation of the Problem and Preliminary Suggestions for Improvement

\begin{tabular}{|c|c|c|c|c|c|}
\hline $\begin{array}{l}\text { Class of } \\
\text { Problems }\end{array}$ & Problems & $\begin{array}{l}\text { Require } \\
\text { ments }\end{array}$ & $\begin{array}{l}\text { Constrai } \\
\text { nts of the } \\
\text { task }\end{array}$ & $\begin{array}{l}\text { Human } \\
\text { costs }\end{array}$ & Suggestions \\
\hline \multirow[t]{2}{*}{ Interfacial } & $\begin{array}{l}\text { Tension } \\
\text { in the } \\
\text { shoulder } \\
\text { s and } \\
\text { back }\end{array}$ & $\begin{array}{l}\text { Decrease } \\
\text { the } \\
\text { distance } \\
\text { of the } \\
\text { tray to } \\
\text { chair }\end{array}$ & $\begin{array}{l}\text { Scoliotic } \\
\text { posture }\end{array}$ & Backache & $\begin{array}{l}\text { New ad- } \\
\text { justable } \\
\text { tray }\end{array}$ \\
\hline & $\begin{array}{l}\text { Tension } \\
\text { in the } \\
\text { lower } \\
\text { limbs }\end{array}$ & $\begin{array}{l}\text { Lower the } \\
\text { platform } \\
\text { to chair }\end{array}$ & $\begin{array}{l}\text { incorrect } \\
\text { posture }\end{array}$ & Leg pain & $\begin{array}{l}\text { Place ad- } \\
\text { justable } \\
\text { chair }\end{array}$ \\
\hline $\begin{array}{l}\text { Physical } \\
\text { Environ } \\
\text { mental }\end{array}$ & $\begin{array}{l}\text { Discom- } \\
\text { fort } \\
\text { gener- } \\
\text { ated by } \\
\text { noise }\end{array}$ & $\begin{array}{l}\text { Reduce } \\
\text { the noise } \\
\text { generated } \\
\text { by } \\
\text { equipmen }\end{array}$ & $\begin{array}{l}\text { Working } \\
\text { in high } \\
\text { noise }\end{array}$ & $\begin{array}{l}\text { Pain, } \\
\text { irritation } \\
\text { and dis- } \\
\text { comfort }\end{array}$ & $\begin{array}{l}\text { Use of PPE } \\
\text { and / or } \\
\text { containmen } \\
\text { t equipment }\end{array}$ \\
\hline Accident & $\begin{array}{l}\text { Operator } \\
\text { runs the } \\
\text { risk of } \\
\text { slipping } \\
\text { and } \\
\text { falling } \\
\text { down to } \\
\text { the } \\
\text { equipme } \\
\text { nt }\end{array}$ & $\begin{array}{l}\text { Decrease } \\
\text { the } \\
\text { amount of } \\
\text { product } \\
\text { that falls } \\
\text { on the } \\
\text { platform } \\
\text { operator }\end{array}$ & $\begin{array}{l}\text { Possibilit } \\
\text { y of } \\
\text { falling }\end{array}$ & $\begin{array}{l}\text { System } \\
\text { dysfuncti } \\
\text { on }\end{array}$ & $\left|\begin{array}{l}\text { Device for } \\
\text { retaining } \\
\text { the product }\end{array}\right|$ \\
\hline
\end{tabular}

Ergonomics. Each operator was asked to respond to each of the previous questions and punctuate according to the values shown in Table 2 .

Table 2

Technical GUT - Gravity X Urgency X Trend

\begin{tabular}{|l|l|l|l|l|}
\hline Valor & Gravity & Urgency & Trend & GxUxT \\
\hline $\mathbf{5}$ & $\begin{array}{l}\text { The damages } \\
\text { and / or diffi- } \\
\text { culties are } \\
\text { extremely } \\
\text { serious. }\end{array}$ & $\begin{array}{l}\text { Immediate } \\
\text { actionis } \\
\text { required. }\end{array}$ & $\begin{array}{l}\text { If nothing is } \\
\text { done the } \\
\text { situation will } \\
\text { worsen soon. }\end{array}$ & 125 \\
\hline $\mathbf{4}$ & Very serious. & $\begin{array}{l}\text { Some ur- } \\
\text { gency. }\end{array}$ & $\begin{array}{l}\text { Will worsen } \\
\text { soon. }\end{array}$ & 64 \\
\hline $\mathbf{3}$ & Grave. & $\begin{array}{l}\text { As soon as } \\
\text { possible. }\end{array}$ & $\begin{array}{l}\text { Will worsen } \\
\text { in the me- } \\
\text { dium term. }\end{array}$ & 27 \\
\hline $\mathbf{2}$ & Mild. & $\begin{array}{l}\text { You can } \\
\text { wait a bit. }\end{array}$ & $\begin{array}{l}\text { Will get } \\
\text { worse, but in } \\
\text { the long term. }\end{array}$ & 8 \\
\hline $\mathbf{1}$ & $\begin{array}{l}\text { Without grav- } \\
\text { ity. }\end{array}$ & $\begin{array}{l}\text { There's no } \\
\text { hurry. }\end{array}$ & $\begin{array}{l}\text { It will get } \\
\text { worse and } \\
\text { may even } \\
\text { improve. }\end{array}$ & 1 \\
\hline
\end{tabular}

Table 3 presents the results of the opinion of the operators where the risk of slipping and falling when getting off the equipment had the highest score, 100, and is considered by them as the worst of all, then they pointed tension in the shoulders, back and limbs lower due to the position you have to take to perform the task and last, but as a score of almost $50 \%$, was appointed the unease generated by excessive noise resulting in headache.

Table 3

Results of the application of Technical GUT Gravity X Urgency X Trend

\begin{tabular}{|c|c|c|c|c|c|}
\hline Category & Problems & G & $\mathbf{U}$ & $T$ & GxUxT \\
\hline Accident & $\begin{array}{l}\text { Operator } \\
\text { runs the risk } \\
\text { of slipping } \\
\text { and falling } \\
\text { downto the } \\
\text { equipment }\end{array}$ & 5 & 4 & 5 & 100 \\
\hline \multirow[t]{2}{*}{ Interfacial } & $\begin{array}{l}\text { Tension in } \\
\text { the shoul- } \\
\text { ders and } \\
\text { back }\end{array}$ & \multirow[t]{2}{*}{4} & \multirow[t]{2}{*}{4} & \multirow[t]{2}{*}{5} & \multirow[t]{2}{*}{80} \\
\hline & $\begin{array}{l}\text { Tension in } \\
\text { the lower } \\
\text { limbs }\end{array}$ & & & & \\
\hline $\begin{array}{l}\text { Physical } \\
\text { environment }\end{array}$ & $\begin{array}{l}\text { Malaise } \\
\text { generated by } \\
\text { noise. }\end{array}$ & 4 & 4 & 3 & \\
\hline
\end{tabular}

And therefore, the results show that attention should be given a problem to the accident, because the risks brought about by him, if so, have immediate effects on the operators. But the subsequent problems should also be addressed to the extent possible, since the damage provided by the operators they will appear in the long term consequences and can lead to huge losses, both for operators and for the system.

\subsection{Levels of discomfort / pain of employers}

In the physical area of the bagging grain was observed that the workplace has a major deficiency in the ventilation system clean-up among other problems observed.

For the Ministry of Health [4], the pain may cause impairment of quality of life and health of human beings. This demonstration of commitment was observed in this work when the bagging grain operators complained of pain while performing their professional activities.

According to data collected in field research through interviews, it was found that $100 \%$ of employees are male, and most employees already working in business for over three years. 
Flexion, extension and trunk rotation, are routine and performed frequently. According [5], these types of movements performed frequently and require great efforts are causes of physical stress that could result, over time, in pain.

To raise the consequences of the effort was fired by the officers applied a scale of pain / discomfort, because, according to [7], one of the main criteria to evaluate the ergonomics of a product is to use a rating scale of discomfort / pain from user opinion. This scale is considered valid and important and often the assessment of discomfort / pain is applied along with a map of the body regions. This is a method where the discomfort / pain felt during the use of a product is attributed to body regions. You are requested to mention the individual regions assessed uncomfortable / painful for getting worse, and so on, until all regions are mentioned.

Table 4 shows the distribution of the number of employees who claimed discomfort in each body part. The region of the waist and lower back were the most mentioned as quite painful when more than $80 \%$ of employees claimed discomfort as the level Enough (4). The dorsal region represented Moderate level of discomfort. The questionnaires were administered in 15 workers after the work shift of 8 hours.

Table 4

Levels of discomfort of the operators at the end of the workday

\begin{tabular}{|c|c|c|c|c|c|}
\hline \begin{tabular}{|c|}
$\begin{array}{c}\text { Levels of discom- } \\
\text { fort/pain }\end{array}$ \\
Body Part \\
\end{tabular} & $\begin{array}{l}\text { (1) } \\
\text { None }\end{array}$ & $\begin{array}{l}\text { (2) } \\
\text { Some }\end{array}$ & $\begin{array}{c}\text { (3) } \\
\text { Moderate }\end{array}$ & $\begin{array}{l}\text { (4) } \\
\text { Fairly }\end{array}$ & $\begin{array}{c}\text { (5) } \\
\text { Intolerable }\end{array}$ \\
\hline 00 neck & $8(53 \%)$ & $4(26 \%)$ & $3(20 \%)$ & $1(0,6 \%)$ & \\
\hline 01cervical & $3(20 \%)$ & $6(40 \%)$ & $5(33 \%)$ & $1(0,6 \%)$ & \\
\hline 02dorsal & & $1(0,6 \%)$ & $13(86 \%)$ & $1(0,6 \%)$ & \\
\hline 03 waist & & & $3(20 \%)$ & $12(80 \%)$ & \\
\hline 04 lumbar & & & $2(13 \%)$ & $13(86 \%)$ & \\
\hline 05 basin & & $2(13 \%)$ & $11(73 \%)$ & $2(13 \%)$ & \\
\hline $\begin{array}{l}\text { 06 left shoul- } \\
\text { der }\end{array}$ & & $2(13 \%)$ & $10(66 \%)$ & $3(20 \%)$ & \\
\hline $\begin{array}{l}07 \text { right } \\
\text { shoulder }\end{array}$ & $1(0,6 \%)$ & $1(0,6 \%)$ & $11(73 \%)$ & $2(13 \%)$ & \\
\hline 08 left arm & $9(60 \%)$ & $4(26 \%)$ & $2(13 \%)$ & & \\
\hline 09 right arm & $8(53 \%)$ & $4(26 \%)$ & $3(20 \%)$ & & \\
\hline 10 left elbow & $12(80 \%)$ & $2(13 \%)$ & $1(0,6 \%)$ & & \\
\hline $\begin{array}{l}11 \text { right el- } \\
\text { bow }\end{array}$ & $11(73 \%)$ & $3(20 \%)$ & & $1(0,6 \%)$ & \\
\hline $\begin{array}{l}12 \text { left fore- } \\
\text { arm }\end{array}$ & $14(93 \%)$ & & $1(0,6 \%)$ & & \\
\hline $\begin{array}{l}13 \text { right fore- } \\
\text { arm }\end{array}$ & $14(93 \%)$ & & $1(0,6 \%)$ & & \\
\hline 14 left wrist & $13(86 \%)$ & $1(0,6 \%)$ & $1(0,6 \%)$ & & \\
\hline 15 right wrist & $11(73 \%)$ & $2(13 \%)$ & $1(0,6 \%)$ & & \\
\hline
\end{tabular}

\begin{tabular}{|l|l|l|l|l|l|}
\hline 16 left hand & $13(86 \%)$ & $1(0,6 \%)$ & $1(0,6 \%)$ & & \\
\hline 17 right hand & $14(93 \%)$ & & $1(0,6 \%)$ & & \\
\hline 18 left thigh & $12(80 \%)$ & $3(20 \%)$ & & & \\
\hline 19 right thigh & $13(86 \%)$ & $1(0,6 \%)$ & & $1(0,6 \%)$ & \\
\hline 20 left knee & $13(86 \%)$ & $2(13 \%)$ & & & \\
\hline 21 right knee & $11(73 \%)$ & $3(20 \%)$ & $1(0,6 \%)$ & & \\
\hline 22 left leg & $13(86 \%)$ & $2(13 \%)$ & & & \\
\hline 23 right leg & $11(73 \%)$ & $3(20 \%)$ & $1(0,6 \%)$ & & \\
\hline 24 left ankle & $13(86 \%)$ & $2(13 \%)$ & & & \\
\hline 25 right ankle & $11(73 \%)$ & $3(20 \%)$ & $1(0,6 \%)$ & & \\
\hline 26 left foot & $13(86 \%)$ & $2(13 \%)$ & & & \\
\hline 27 right foot & $11(73 \%)$ & $3(20 \%)$ & $1(0,6 \%)$ & & \\
\hline
\end{tabular}

According to [3], fatigue is the effect of continuous work, which causes a reversible reduction of the ability of an organism and qualitative degradation of this work. Related to fatigue, there are physiological factors (intensity and duration of physical and mental work), the psychological factors (boredom and lack of motivation) and social and environmental factors (lighting, noise, temperature and social relationships with management and co-workers).

Other topics verified that cause fatigue are bagging the physiological factors related to intensity and duration of physical work in addition to psychological factors as the pace set by the collection of productivity and working hours long and indeterminate, since only end when the work was fully completed with about 400 bags per hour.

The data on the types of professional activities developed to the conclusion that by checking the positions, duties performed, the dominant movements and effort demanded by the workers in carrying out its functions, it is possible to reduce fatigue and, consequently, ain, which can be minimized by getting more income.

\subsection{Preliminary suggestions for improvements}

As immediate action should be made are arrangements of facilities by defining a new layout for the solution of problems encountered. In addition to this measure, the items should assess the NR 17, dealing with ergonomics and which aims to establish parameters for the adaptation of working conditions to the psychophysiological characteristics of workers, in order to provide maximum comfort, safety and performance. 
The suggestions are to create regular breaks and formalized system of wheels with teams of operators to reduce the physical effort; tailor the job according to the anthropometric characteristics of the user with the creation of a technical device that allows adjustments in height and approach the magazine (retractable arm) and support for the legs; adequate access to the workplace; confinement of equipment that include the bagging grains to minimize the noise level and the use of PPE.

\section{Discussion}

The ergonomic evaluation is provided in the Brazilian legislation, through the NR 17, Norm supervised by the Ministry of Labor. The study of this standard gave guidance in the research and management of work which involves aspects of human, economic, social and environmental, along with other rules and books that deal with this subject.

When we do surveys, task analysis and reformulation of the conditions of employment in bagging grains were identified elements that interfere in working conditions and therefore the satisfaction of operators from intense physical exertion, repetition, posture as a result of inadequate facilities used to implement the process of bagging grain.
Thus, we conclude that good of job added to the good organization of work are starting to work on issues of content of work (man-machine). In ergonomics, the modification to the environment, jobs and work organization in general, varies with the needs, interests and capabilities of each company. The intention is that once identified the problems and listed solutions for process improvement, and if accepted, is that assessments are made before and after ergonomic intervention implemented by, for example, comparing the satisfaction of operators.

\section{References}

[1] A. Moraes, C. Mont'alvão, Ergonomia conceitos e aplicações, Rio de Janeiro: 2AB, 2010.

[2] E. Grandjean, K. H. E. Kroemer, Manual de Ergonomia: adaptando ao trabalho do homem. Porto Alegre: Bookman 2005.

[3] I. Iida, Ergonomia: projeto e produção, São Paulo: Edgard Blücher, 2009.

[4] Brazil's Ministry of Health, Center for Oncology, Brasília. Available at $<$ http://portal.saude.gov.br/saude/>. Accessed: 20 maio 2010.

[5] P. Pequini, Intervenção ergonômica e suas implicações na produtividade e satisfação dos funcionários: estudo de caso de lavanderia industrial, Faculdade Área 1, 2007.

[6] Petroquisa, Petrobras starts sale of granulated urea in Brazil, Available at http://www.petroquisa.com.br/Pagina

Dinamica.asp Grupo $=250 \&$ Publicacao $=578 \&$ APRES $=$ PUBL

$\& W T=1 \& I D \_$home $=$HOME45\&ID_noticias $=$Petrobras + inicia + come rcializa $\% \mathrm{E} 7 \% \mathrm{E} 3 \mathrm{o}+\mathrm{de}+\mathrm{ur} \% \mathrm{E} 9 \mathrm{ia}+$ granulada+no+Brasil-

578\&ID_TIPO=P, Accessed 02 dez 2010.

[7] [6] S. Mariño Pequini, Ergonomia aplicada ao design de produtos: Um estudo de caso sobre o design de bicicletas, Ph.D, Dissertation, FAU/USP, São Paulo, 2005. 